DOI https://doi.org/10.30525/978-9934-26-046-9-12

\title{
PECULIARITIES OF IT-PROJECT MANAGEMENT FROM THE POINT OF VIEW OF INNOVATION SCIENCE
}

\author{
Nos M. M. \\ Postgraduate Student \\ National Aerospace University «Kharkiv Aviation Institute»
}

Revenko D. S.

Candidate of Economic Sciences, Associate Professor

National Aerospace University «Kharkiv Aviation Institute»

Filipkovska L. O.

Ph.D. (Engineering Sciences), Associate Professor

National Aerospace University "Kharkiv Aviation Institute»

Kharkiv, Ukraine

The innovative model of economic growth, being aspired to by the majority of the world countries, demands establishing brand new development mechanisms among which the main part is played by information and communication technologies that, in their turn, are a «locomotive» of the world economy development [2]. Progress in the information technology market demonstrates a highly dynamic nature. First of all, this is caused by their being implemented in all fields of human life and activity, and secondly, by their growing in terms of significance and a multiple-aspect character, which requires the development and implementation of new management methods for IT-projects that are mostly innovative by their nature; the factors stated above make the research topic timely and up-to-date.

A significant contribution to the investigation of IT-project management problems has been made by the following scientists: V. Nikolaienko, V. Grekul, N. Korovkina, Ye. Zaramenskyi, A. Katrenko, V. Morozov, S. Dotsenko. At the same time, the methodological approaches mentioned above do not provide us with the systematization of methods of IT-project management effectiveness estimation, which are based on considering those projects as innovations and establishing their impact on the results of the work of companies [3]. Hence, the aim of the research is formulated as the generalization of modern approaches to management of IT-projects as innovative developments. 
An IT-project is a special project. Unlike traditional ones, it has a postimplementation stage which incorporates maintenance, support, improvement, training, etc. All these processes demand extra expenditures. Most IT-projects are a combination of investment and innovation projects. The most important feature of an innovative project is carrying out a complex estimation of the influence of the predicted project results on strategic, environmental, organizational and technological aspects of a company [1].

Distinctive features of IT-projects in terms of the innovative approach are as follows:

- an individual and innovative character of work being conducted within an IT-project;

- IT service peculiarity from the point of view of the subject area;

- intellectual complexity of an IT-project;

- a functional variety of activities in IT-projects, which demands participation of different experts specializing in certain IT areas;

- continuous correction of work within the framework of an IT-project completion .

One of the ways to improve the IT-project management, taking into account innovation science, is the development of an integral approach to the IT-project management, where innovation management stages would play an important role. This will allow solving the following problems: better justification of IT-project selection, elimination of equal risks, more effective control of project cost and quality, effective distribution of human and financial resources.

Conclusions. The work outlines peculiarities of IT-project management from the point of view of innovation science, takes into account peculiarities of IT-projects and formulates the way of solving the problem on the basis of developing an integral approach. Further research will be dedicated to an attempt of developing and implementing an integral approach to management of IT-projects as innovative ones.

\section{References:}

1. Філіпковська Л. О., Нос М. М. Дослідження підходів до управління вартістю інноваційних проектів / Л. О. Філіпковська, М. М. Нос. Управління проектами та розвиток виробництва: Зб. наук. пр. Луганськ: вид-во СНУ ім. В. Даля, 2018 №4(68). С. 5-15.

2. Соолятэ А. Ю. Управление проектами в компании: методология, технологи, практика. Учебник. М.: Синергия, 2016. 816 с.

3. Стиллмен Э., Грин Д. Head First Agile. Гибкое управление проектами. Учебник. Санкт-Петербург, Питер, 2019. 464 с. 